Evans, W. (1931) The pathology and aetiology of brain abscess. Lancet, i, 1231.

GARDFIELD, J. (1969) Management of supra-tentorial intracranial abscess: A review of two hundred cases. British Medical Journal, ii, 7.

Gates, E.M., Kernohan, J.W. \& McCraig, W. (1950) Metastatic brain abscess. Medicine, 29, 71.

JefFerson, M. \& Rosenthal, F.D. (1959) Spontaneous necrosis in pituitary tumours. (Pituitary apoplexy). Lancet, i, 342.

Jooma, O.V., Pennybacker, J.B. \& Tutton, G.K. (1951) Brain abscess: Aspiration, drainage or excision. Journal of Neurology, Neurosurgery and Psychiatry, 14, 308.

Krayenbuhl, H.A. (1967) Abscess of the brain. Clinical Neuro-surgery, 14, 25.

Lindholm, J., Rasmussen, P. \& KorsgaARd, O. (1973) Intra-sellar or pituitary abscess. Journal of Neurosurgery, 38, 616.

Liske, E. \& Weikers, N.J. (1964) Changing aspects of Brain Abscesses. Neurology (Minneapolis), 14, 294.
Loeser, E. \& Scheinberg, L. (1957) Brain abscesses. Neuro$\log y$ (Minneapolis), 7, 601.

Milenkovic, P. (1961) Abscesses in the hypophyseal cavity. Srpski archiv za celokupno lekarstvo, 89, 883.

Nelson, D.A., Holloway, W.J., Karaeneff, S.C. \& GolDENBERG, H.I. (1967) Neurological syndromes produced by sphenoid sinus abscess with neuroloradiologic review of pituitary abscess. Neurology (Minneapolis), 17, 981.

Paillas, J.E. \& Aymard, J. (1956) Les abcès de l'hypophyse. Presse Médicale, 64, 1081.

Svien, A.J. \& Love, J.G. (1942) Abscess within the sella turcica simulating a pituitary tumor: Surgical cure. Proceedings of Staff Meetings of the Mayo Clinic, 17, 497.

TweED, R.W. (1938) Meningitis from the sphenoid sinus. Archives of Otolaryngology, 28, 589.

Whalley, N. (1952) Abscess formation in a pituitary adenoma. Journal of Neurology, Neurosurgery and Psychiatry, 15, 66.

\title{
Effect of hypocalcaemia on glucose tolerance, insulin release and free fatty acid levels in human subjects
}

\author{
S. BANSAL \\ M.D. \\ S. N. A. RIZVI
M.D. \\ M. B. RAO \\ M.D., M.R.C.P. \\ H. VAISHNAVA \\ F.R.C.P.E. \\ Metabolism and Endocrinology Unit, Department of Medicine, Maulana Azad Medical \\ College and Associated Irwin and G. B. Pant Hospitals, New Delhi, India
}

\begin{abstract}
Summary
Eight patients with hypocalcaemia who presented with frank or latent tetany due to parathyroid insufficiency or nutritional osteomalacia were studied. Their serum calcium ranged from 6.85 to $7.7 \mathrm{mg} / 100 \mathrm{ml}$ (mean $7 \cdot 33 \pm 0 \cdot 36 \mathrm{mg} / 100 \mathrm{ml}$ ). In six of them, serum calcium after treatment varied from 8.4 to $9.2 \mathrm{mg} / 100 \mathrm{ml}$. In ten healthy normal subjects the serum calcium levels were $9 \cdot 0-10 \cdot 2 \mathrm{mg} / 100 \mathrm{ml}(9 \cdot 50 \pm 0.47 \mathrm{mg} / 100 \mathrm{ml})$. The blood glucose levels during a $3 \mathrm{hr}$ oral GTT were significantly elevated during hypocalcaemia and returned to normal levels after treatment. Serum insulin levels were low at 60 and $120 \mathrm{~min}$ after the administration of glucose in hypocalcaemia but returned to normal once the serum calcium levels were above $8.4 \mathrm{mg} / 100 \mathrm{ml}$. The FFA levels were high during the low calcium state and reached normal levels after treatment. The above studies suggest that an optimal level of serum calcium is essential for glucose-induced insulin release.
\end{abstract}

Reprints requests: Dr S. N. A. Rizvi, Maulana Azad Medical College and Associated Hospitals, New Delhi, India.

\section{Introduction}

Many 'secretary cells', which store their products in granules or vesicles, need extracellular ionic calcium for the release of their secretions (Rasmussen, 1964). The release of insulin from the beta cells of the pancreas is also dependent on the presence of extracellular ionic calcium (Curry, Bennett and Grodsky, 1968). The purpose of this study was to observe alteration in glucose tolerance, insulin release and free fatty acid levels in response to an oral glucose load in hypocalcaemic and normocalcaemic states in the same patients.

\section{Materials and methods}

The subjects for this study comprised two groups: group I consisted of eight female patients having hypocalcaemia due either to primary hypoparathyroidism or vitamin $\mathbf{D}$ deficiency osteomalacia. They were non-obese and non-diabetic and had no family history of these diseases. They were free from gastrointestinal, liver or kidney disease. Group II consisted of ten healthy normal non-diabetics, who 
were age- and sex-matched and were free from gastrointestinal, bone or endocrinal diseases. The latter also did not give a family history of diabetes or obesity and were used as controls.

An oral glucose tolerance test was performed using $100 \mathrm{~g}$ of glucose and the samples were drawn at 0 , 60,120 and $180 \mathrm{~min}$ to estimate blood glucose (Asatoor and King, 1964), plasma free fatty acids (Anastall and Trujillo, 1965), serum immunoreactive insulin (Hales and Randle, 1963) and serum calcium (Ray Sarkar and Chauhan, 1967). Ancillary investigations to assess the cause of hypocalcaemia were also carried out. These included serum phosphorus and alkaline phosphatase (Asatoor and King, 1964), 24-hr urinary excretion of calcium, phosphorus and creatinine, calcium infusion test (Nordin and Fraser, 1956), phosphorus excretion index, percentage tubular resorption of phosphorus, serum sodium, potassium, magnesium and chloride, total and differential serum proteins. Radiological surveys and histopathological examination of bone were carried out to confirm the diagnosis in cases of osteomalacia.

Gastrointestinal functions (including fat balance and D-xylose tests) were carried out in both the groups. Biochemical investigations were repeated after the signs of latent tetany disappeared and the serum calcium levels rose.

\section{Results}

In six of the eight hypocalcaemic patients, serum calcium levels returned to $8.4 \mathrm{mg} / 100 \mathrm{ml}$ and above with treatment. Latent tetany disappeared at this stage. Their initial serum calcium values estimated twice varied between 6.85 and $7.70 \mathrm{mg} / 100 \mathrm{ml}$ (mean $7.33 \pm 0.36 \mathrm{mg} / 100 \mathrm{ml}$ ). Total and differential serum proteins and serum electrolytes $\left(\mathrm{Na}^{+}, \mathrm{K}^{+}, \mathrm{Mg}^{++}\right.$, $\mathrm{Cl}^{-}$) were within normal limits. Six of them, after treatment, showed serum calcium values of $8 \cdot 4-9 \cdot 2$ $\mathrm{mg} / 100 \mathrm{ml}$ (mean $8 \cdot 87 \pm 0.33 \mathrm{mg} / 100 \mathrm{ml}$ ). In the controls serum calcium ranged between 9.0 and $10.2 \mathrm{mg} / 100 \mathrm{ml}$ (mean $9.50 \pm 0.47 \mathrm{mg} / 100 \mathrm{ml}$ ).

The weights of the patients were comparable to the control group and no appreciable change in body weight was noticed after correction of the hypocalcaemia. Gastrointestinal functions including fat balance and D-xylose tests did not reveal any evidence of malabsorption syndrome.

The serum immunoreactive insulin levels are shown in Fig. 1 and Table 1. They show that the insulin release was significantly reduced at 60 and $120 \mathrm{~min}$ and returned to normal when the serum calcium values were $8.4 \mathrm{mg} / 100 \mathrm{ml}$ and above. There was no linear correlation between the degree of insulin release and the severity of hypocalcaemia. The values obtained for glucose tolerance test are shown in Table 2 and Fig. 2. During the hypocalcaemic state there were high levels of blood

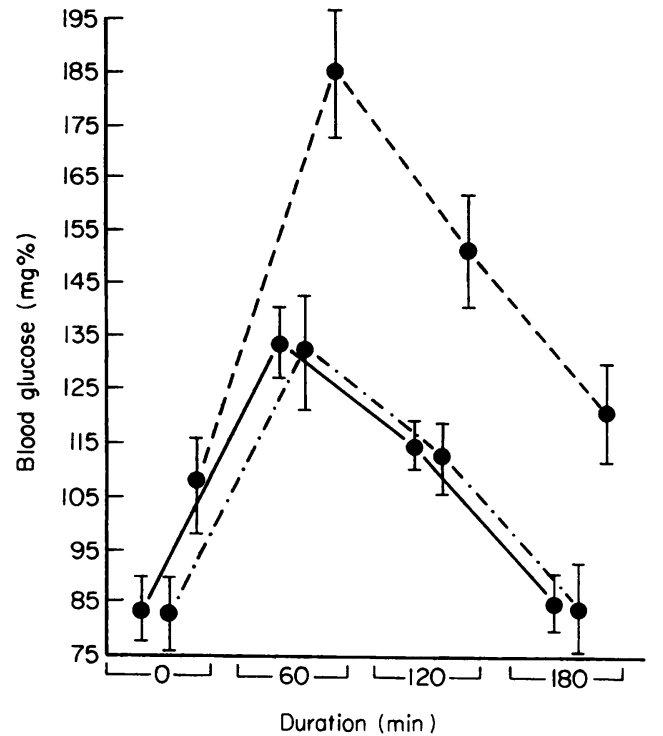

FIG. 1. IRI-levels after $100 \mathrm{gm}$ glucose. - , control cases; - - - cases of hypocalcaemia; - - - - . after treatment of hypocalcaemia.

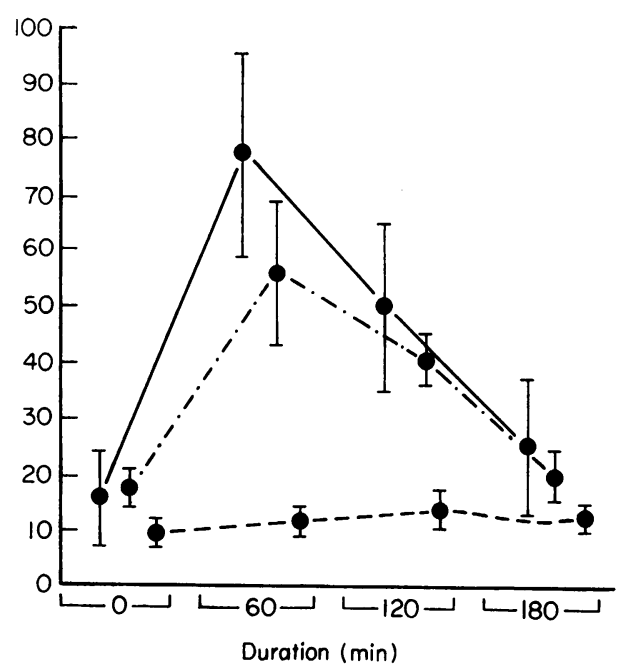

Fig. 2. Glucose tolerance test.- - - cases of hypocalcaemia; - _. - - , after treatment of hypocalcaemia.

glucose which returned to normal after treatment. The results of plasma free fatty acid estimations are given in Table 3 and Fig. 3. These showed high levels of FFA associated with hypoinsulinaemia.

During the $180 \mathrm{~min}$ oral glucose tolerance test, the insulin and glucose increments at each sampling 


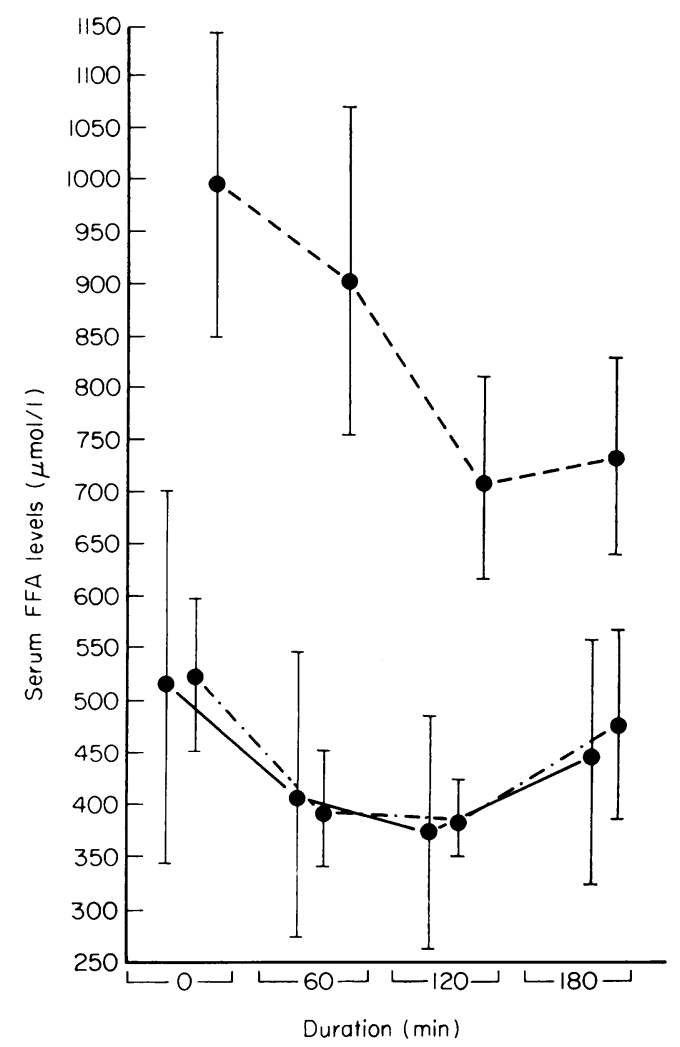

Fig. 3. Serum FFA levels after $100 \mathrm{gm}$ glucose. control subjects; - - , cases of hypocalcaemia; - . - . - , after treatment of hypocalcaemia.

time was calculated. Insulinogenic index, which is the result of the serum insulin concentration at a specified time minus the fasting serum insulin concentration $(\triangle I)$, and the blood glucose concentration at that time minus the fasting blood glucose concentration $(\triangle \mathbf{G})$ shows that insulin release is proportionately reduced in calcium-deficient states and returns to normal after treatment of hypocalcaemia (Fig. 4).

\section{Discussion}

Participation of calcium ion in the mechanism of secretion of insulin is well established by in vitro studies (Rasmussen, 1964). Grodsky and Bennett (1966), using the isolated perfused pancreas of the rat, showed that glucose fails to stimulate insulin release in the absence of calcium ions in the perfusate. This work was confirmed by others, using in vitro techniques (Milner and Hales, 1967; Lambert et al., 1969). Salvesen (1954) showed comparable results in two dogs and a female patient. Garmitta and Stoner (1970) have shown reversible glucose intolerance in three patients with hypocalcaemia. Similar observations have been made in spontaneously developing hypocalcaemia in post-parturient cows (Wilson, Blum and Kronfeld, 1971). In vitro studies with radioactive calcium (Littledike, Witzel and Whipp, 1968) have shown that during glucose metabolism the beta cells take up ionic calcium; an interaction between calcium and microtubular-microfilamentous system (MMS) then takes place, resulting in emiocytosis of the secretory granules. Dibutyrylcyclic AMP causes insulinotropic action of glucose to be restored in calcium-depleted media. The insulinotropic action of cyclic AMP is believed to be due to a glucose-independent intracellular translocation of ionic calcium from an organelle bound pool to a cytoplasmic pool readily available for transport across the cell membrane (Malaisse, Brisson and Maliasse-Lagae, 1971).

Insulin release was markedly reduced in hypocalcaemic patients as compared to the controls and the treated patients. The levels of insulin in fasting patients were not significantly different from the normal but were so 60 and $120 \mathrm{~min}$ after glucose. The results compare favourably with the insulinogenic indices given by Carmitta and Stoner (1970) in two of their three patients while in the third the values were high. They therefore postulated some sort of peripheral antagonism in the last patient. This was not seen in any of our eight patients. As a result of hypoinsulinaemia, blood glucose levels were elevated and returned to normal when insulin levels were restored. Free fatty acid levels were elevated

TABle 1. Plasma insulin levels $(\mu \mathrm{u} / \mathrm{ml})$

\begin{tabular}{cccc}
\hline & & \multicolumn{2}{c}{ Hypocalcaemics } \\
\cline { 3 - 4 } $\begin{array}{c}\text { Time in } \\
\text { min }\end{array}$ & Normals & $\begin{array}{c}\text { Before } \\
\text { treatment }\end{array}$ & $\begin{array}{c}\text { After } \\
\text { treatment }\end{array}$ \\
\hline 0 & $15 \cdot 8 \pm 9 \cdot 25$ & $9 \cdot 9 \pm 2 \cdot 27$ & $17 \cdot 3 \pm 3 \cdot 12$ \\
& $(6-42)$ & $(6-12)$ & $(14-22)$ \\
60 & $77 \cdot 8 \pm 18 \cdot 53$ & $12 \cdot 0 \pm 2 \cdot 60$ & $58 \cdot 5 \pm 16 \cdot 10$ \\
& $(43-98)$ & $(8-17)$ & $(38-88)$ \\
120 & $49 \cdot 8 \pm 14 \cdot 99$ & $13 \cdot 70 \pm 2 \cdot 46$ & $41 \cdot 0 \pm 6 \cdot 61$ \\
& $(30-84)$ & $(10-16)$ & $(32-54)$ \\
180 & $25 \cdot 5 \pm 12 \cdot 12$ & $13 \cdot 1 \pm 2 \cdot 00$ & $20 \cdot 1 \pm 4 \cdot 02$ \\
& $(15-60)$ & $(10-16)$ & $(16-26)$ \\
\hline
\end{tabular}


TABLE 2. Blood glucose levels $(\mathrm{mg} / 100 \mathrm{ml})$

\begin{tabular}{cccc}
\hline & & \multicolumn{2}{c}{ Hypocalcaemics } \\
\cline { 3 - 4 } $\begin{array}{c}\text { Time in } \\
\text { min }\end{array}$ & Normals & $\begin{array}{c}\text { Before } \\
\text { treatment }\end{array}$ & $\begin{array}{c}\text { After } \\
\text { treatment }\end{array}$ \\
\hline 0 & $83 \cdot 9 \pm 5 \cdot 35$ & $106 \cdot 8 \pm 8 \cdot 77$ & $82 \cdot 5 \pm 6 \cdot 63$ \\
& $(75-93)$ & $(95-125)$ & $(74-94)$ \\
60 & $132 \cdot 6 \pm 6 \cdot 34$ & $183 \cdot 4 \pm 11 \cdot 91$ & $131 \cdot 8 \pm 10 \cdot 70$ \\
& $(123-139)$ & $(165-208)$ & $(115-146)$ \\
120 & $114 \cdot 1 \pm 3 \cdot 96$ & $150 \cdot 1 \pm 10 \cdot 62$ & $111 \cdot 8 \pm 6 \cdot 94$ \\
& $(106-119)$ & $(135-167)$ & $(105-122)$ \\
180 & $85 \cdot 4 \pm 5 \cdot 92$ & $120 \cdot 3 \pm 7 \cdot 92$ & $83 \cdot 8 \pm 8 \cdot 19$ \\
& $(75-98)$ & $(106-132)$ & $(75-98)$ \\
\hline
\end{tabular}

TABLE 3. Serum free fatty acid levels $(\mu \mathrm{mol} / \mathrm{l})$

\begin{tabular}{cccc}
\hline & & \multicolumn{2}{c}{ Hypocalcaemics } \\
\cline { 3 - 4 } $\begin{array}{c}\text { Time in } \\
\text { min }\end{array}$ & Normals & $\begin{array}{c}\text { Before } \\
\text { treatment }\end{array}$ & $\begin{array}{c}\text { After } \\
\text { treatment }\end{array}$ \\
\hline 0 & $519 \cdot 1 \pm 176 \cdot 72$ & $995 \cdot 6 \pm 143 \cdot 79$ & $523 \cdot 3 \pm 67 \cdot 70$ \\
& $(298-843)$ & $(788-1234)$ & $(454-628)$ \\
60 & $382 \cdot 1 \pm 137 \cdot 27$ & $808 \cdot 4 \pm 154 \cdot 695$ & $395 \cdot 5 \pm 58 \cdot 86$ \\
& $(235-642)$ & $(592-1067)$ & $(332-475)$ \\
120 & $379 \cdot 7 \pm 102 \cdot 93$ & $711 \cdot 1 \pm 94 \cdot 38$ & $386 \cdot 3 \pm 34 \cdot 58$ \\
& $(248-567)$ & $(578-878)$ & $(350-458)$ \\
180 & $444 \cdot 4 \pm 110 \cdot 45$ & $729 \cdot 8 \pm 90 \cdot 64$ & $476 \cdot 2 \pm 90 \cdot 38$ \\
& $(315-712)$ & $(582-856)$ & $(396-637)$ \\
\hline
\end{tabular}

during hypocalcaemia and returned to normal after treatment when the levels of serum calcium rose above $8.4 \mathrm{mg} / 100 \mathrm{ml}$. As far as we know there is no other study available for comparison with these results.

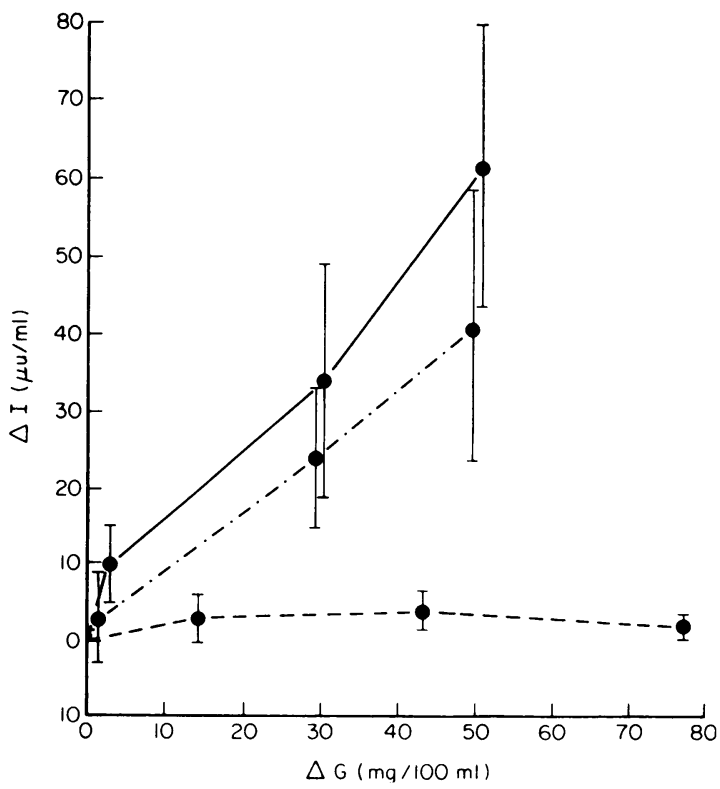

Fig. 4. $\Delta I / \triangle G$ after $100 \mathrm{~g}$ glucose, $\longrightarrow$, control subjects; - - - cases of hypocalcaemia; - - - - cases of hypocalcaemia after treatment.
From these observations it can be surmised that the presence of calcium is necessary for the proper release of insulin from the beta cells.

\section{Acknowledgments}

Our thanks are due to Dr P. Kansal and Dr R. K. Goyal for initially suggesting this idea to us, to Mr B. M. Sharma for technical assistance, and to the medical and nursing staff of the metabolic ward for their co-operation.

\section{References}

ANASTall, H.B. \& Trujillo, J.M. (1965) Determination of free fatty acids in plasma by a calorimetric procedure. An appraisal of the method and comparison with the techniques. Clinical Chemistry, 11, 741.

Asatoor, A. \& KING, E.J. (1964) In: Microanalysis in Medical Biochemistry. (Ed. by E. J. King and I. D. P. Wooton), 4th edn. J. \& A. Churchill, Ltd., London.

Carmitta, F.D. \& Stoner, R.E. (1970) Abnormal glucose and insulin response to oral glucose during hypocalcaemia. Diabetes, 19, 380.

Curry, D.L., BennetT, L.L. \& Grodsky, G.M. (1968) Dynamics of insulin secretion by the perfused rat pancreas. Endocrinology, 83, 572.

GRoDSky, G.M. \& BeNNETT, L.L. (1966) Cation requirements for insulin secretion in the isolated perfused pancreas. Diabetes, 15, 910.

Hales, C.N. \& Randle, P.J. (1963) Immunoassay of insulin antibody precipitate. Biochemical Journal, 88, 137.

Lambert, A.E., Jeavenand, B., Junod, A. \& Renold, A.E. (1969) Organ culture of foetal rat pancreas. II Insulin release induced by amino and organic acids by hormonal peptides, by cationic alterations of medium and by other agents. Biochemica et biophysica acta, 174, 540. 
LitTledike, E.T., Witzel, D.A. \& WhipP, S.C. (1968) Insulin: Evidence for inhibition of release in spontaneous hypocalcaemia. Proceedings of the Society for Experimental Biology and Medicine, 129, 135.

Malaisse, W.J., Brisson, W.R. \& Maliasse-Lagae, F. (1971) Cyclic AMP-induced translocation of calcium in isolated beta cells. Diabetes, $20,328$.

Milner, R.D.G. \& Hales, C.N. (1967) The role of calcium and magnesium in insulin secretion from rabbit pancreas studied in vitro. Diabetologia, 3, 47.

NoRdin, B.E.C. \& Fraser, R. (1956) A calcium infusion test. I. Urinary excretion data for recognition of osteomalacia. Lancet, i, 823
RASMUSSEN, H. (1964) Effects of calcium upon cellular metabolism. Annals of Internal Medicine, 60, 526.

Ray Sarkar, B.C. \& Chauhan, U.P.S. (1967) A new method for determining microquantities of calcium in biological materials. Analytical Biochemistry, 20, 155.

SAlvesen, H.A. (1954) A note on the relation of the parathyroids to carbohydrate metabolism. Acta endocrinologica, 16, 349.

Wilson, R.B., Blum, J.W. \& Kronfeld, D.S. (1971) Plasma calcium, glucose and insulin concentrations in hypocalcaemic parturient cows. Diabetes, 20, 382.

Postgraduate Medical Journal, (July 1975) 51, 475-477.

\section{A brainstem syndrome associated with Mycoplasma pneumoniae infection-A report of two cases*}

\author{
S. J. JACHUCK \\ B.Sc., M.B., B.S \\ F. Clark \\ M.B., B.S., F.R.C.P.
}

C. GARDNER-THORPE $\dagger$
M.B., B.S. M.R.P.

J. B. Foster

M.B., B.S., F.R.C.P.

The Departments of Medicine and Neurology, Newcastle University Hospital Group, Newcastle upon Tyne, NE4 6BE

\section{Summary}

Two patients with a serologically-proved infection with Mycoplasma pneumoniae (MP) developed cranial nerve pareses which cleared spontaneously within 1 month of the onset. The sixth and seventh cranial nerves were the most severely affected. It is suggested that the signs were due to a mild brainstem encephalitis associated with the MP infection. The benign course of the syndrome is emphasized. The neurological complications of MP infection may be commoner than has been generally supposed.

\section{Introduction}

Simultaneous multiple cranial nerve palsies in young adults are uncommon. In a significant proportion of cases a structural cause is not found. In some patients an episode of brainstem demyelination can be incriminated. Rare causes include sarcoidosis, post-infective radiculopathy, diabetes mellitus, encephalitis, diphtheria and spinal anaesthesia. The term 'rheumatic neuritis' has been used in some cases

\footnotetext{
*Reprints requests to Dr S. J. Jachuck, The Departments of Medicine and Neurology, Newcastle University Hospital Group, Newcastle upon Tyne NE4 6BF.

$\dagger$ Present address: Department of Neurology, Royal Devon and Exeter Hospital (Wonford), Barrack Road, Exeter, Devon, England.
}

in which a definite diagnosis cannot be made (Brain and Walton, 1969).

Although pneumonitis is probably the commonest clinical presentation of infection with $M$. Pneumoniae, it is known that the nervous system may also be involved (Yeshnick, 1956; Taylor et al., 1967; Hodges, Fass and Saslow, 1972; Endtz et al., 1972), especially in men and in the young. Eighth cranial nerve involvement has been described in only two patients (Dishoeck, 1963). Four varieties of neurological complication, each with distinct cerebrospinal fluid changes, have been reported in the literature-

(1) Psychosis, usually in the elderly; (2) meningoencephalitis; (3) meningitis; (4) radiculopathy.

The purpose of this paper is to report the combination of unilateral sixth (abducent) and seventh (facial) cranial nerve palsies in two patients with seroligical evidence of $M$. pneumoniae infection.

\section{Case reports}

\section{Case 1}

A 30-year-old electrician, noticed double vision on looking to the left, together with weakness of the left side of the face, on 26 June 1973. He had previously been well and had not noticed any other neurological symptoms. He was admitted 